\title{
EFFECT OF MESOPOROSITY ON SPECIFIC CAPACITANCE OF CARBONS
}

J.A. Fernández ${ }^{a}$, S. Tennison ${ }^{b}$, O.Kozynchenko ${ }^{b}$, F. Rubiera ${ }^{a}$, F. Stoeckli ${ }^{c}$, T.A. $^{2}$ Centeno $^{*}$,

a Instituto Nacional del Carbón-CSIC. Apartado 73, E-33080 Oviedo, Spain

${ }^{b}$ MAST Carbon International Ltd., Henley Park, Guildford, Surrey, GU3 2AF, United Kingdom

${ }^{c}$ Physics Department, University of Neuchâtel. Rue Emile Argand 11, CH-2009 Neuchâtel, Switzerland

\begin{abstract}
The study compares the structural and electrochemical properties of 12 porous carbons based on phenolic resins, using both aqueous $\left(\mathrm{H}_{2} \mathrm{SO}_{4}\right)$ and aprotic $\left(\left(\mathrm{C}_{2} \mathrm{H}_{5}\right)_{4} \mathrm{NBF}_{4}\right.$ in acetonitrile) electrolytes. It appears that they fit into the general pattern observed for other carbons. The present carbons have micropore volumes varying between 0.29 and $0.66 \mathrm{~cm}^{3} \mathrm{~g}^{-1}$ and average pore widths $\mathrm{L}_{\circ}$ between 0.62 and $1.23 \mathrm{~nm}$. Five samples are exclusively microporous, whereas seven also display a relatively important mesoporosity. This allows a direct comparison between pairs of carbons with similar micropore systems, with and without mesopores, in order to assess the role of mesoporosity in the electrochemical properties. It appears that mesopores have only a limited influence on the decrease in capacitance at high current density as opposed to earlier assumptions.
\end{abstract}

\footnotetext{
* Corresponding author. Tel.: + 34.985119090

E-mail address: teresa@incar.csic.es
} 


\section{Introduction}

Although the level of performance of current-generation supercapacitors (SCs) is sufficient for certain applications, the full potential of these systems has yet to be realized [1]. The improvement of such devices will benefit from recent insights into the relationships between the porous and chemical characteristics of carbons and their performance as electrodes in electric double layer capacitors (EDLCs) [2].

Systematic studies at low current density have already shown that the specific capacitance in aqueous electrolytes such as $\mathrm{H}_{2} \mathrm{SO}_{4}$ and $\mathrm{KOH}$ depends on a contribution from the total surface area and from redox processes involving surface functionalities [2-7]. Moreover, it has been shown [6] that the contributions from the microporous and the external (meso- and macropores) surface areas are identical, as opposed to an earlier hypothesis [8].

In the case of aprotic electrolytes with bulkier ions (e.g. $\left(\mathrm{C}_{2} \mathrm{H}_{5}\right)_{4} \mathrm{NBF}_{4}$ in acetonitrile) and ionic liquids such as EMI-TFSI, the accessibility of the micropores may be considerably reduced for carbons with narrow pores (width $<0.7 \mathrm{~nm}$ ) or showing 'gate' effects at the pores entrance $[2,7,9,10]$. On the other hand, the contribution from pseudocapacitance effects in the $\left(\mathrm{C}_{2} \mathrm{H}_{5}\right)_{4} \mathrm{NBF}_{4}$ /acetonitrile electrolyte appears to be negligible compared to the aqueous media and the supercapacitor performance is essentially based on a double-layer mechanism through the extent of the accessible (effective) surface area of the carbon $[2,9,10]$.

As the charge rate and/or the frequency increase, electrolyte penetration becomes poorer and less surface area is accessed. The hindering of ion transfer in the randomly connected micropores also leads to higher resistance. As a consequence, the formation of an effective double-layer fails notably at high current density and the energy and power density of super capacitor drop [1, 2]. 
The present work is based on the systematic analysis of the performance of phenolic resin-derived carbons, using vapour adsorption, immersion calorimetry and electrochemical techniques. It confirms the general trends reported earlier for other types of carbons examined by using exactly the same experimental protocols $[6,9$, 10].

The study also challenges the long-held presumption that pores larger than $2 \mathrm{~nm}$ significantly enhance the capacitor performance by providing wider transport paths for ions diffusion into smaller pores $[2,11-16]$. This observation is made possible by the fact that the present series of carbons, based on the same precursor, contains samples of similar microporous structures (average widths $L_{o}$ between 0.6 and 1.2 $\mathrm{nm}$ ) and variable mesoporous volumes. This approach provides more detailed understanding of processes at the electrode/electrolyte interface of carbons.

\section{Experimental}

\subsection{Carbons}

Twelve porous carbons were developed and produced by MAST Carbon using a phenolic resin as raw material.

Phenolic resin is widely used as a carbon precursor for both porous and structural materials due to the high carbon yields ( $\sim 50 \%$ weight $)$ and the porous structures that can be achieved [17]. The micropore structure $(<2 \mathrm{~nm})$ derives initially from phase separation that occurs during the resin curing process when the thermoplastic novolak is converted to the cross linked resin, usually using hexamethylene tetramine (hex). This gives rise to small uniform sized domains of around $6 \mathrm{~nm}$ diameter of high molecular weight cross linked resin in a matrix of lower molecular weight, less cross linked resin.

During the carbonisation process at $800^{\circ} \mathrm{C}$ the high molecular weight domains convert to interlinked spherical domains of high density, low porosity, glassy carbon 
whilst the lower molecular weight matrix is largely decomposed creating the primary microporosity. This structure can be further modified by activation in carbon dioxide at temperatures in excess of $900^{\circ} \mathrm{C}$. The initial effect is to remove more reactive pyrocarbon deposits from the low reactivity glassy carbon nanoparticles. More severe activation ultimately removes some of the nanoparticles and also probably creates some surface porosity in the nanoparticles [18].

Controlled meso (2-5 nm) and macroporosity is introduced into these carbons by the addition of a solvent pore former (ethylene glycol) prior to the resin curing step [19]. As the resin cures, it becomes insoluble in the solvent pore former leading to phase separation and the generation of large, interconnected voids. The meso/macro pore size and pore volume is controlled by increasing the solvent:resin ratio used in the preparation. These larger pores are generated without any significant modification to the micropore structure.

\subsection{Characterization of the textural and chemical properties of the carbons}

The porous structure of the carbons was evaluated by the classical analysis of the $\mathrm{N}_{2}$ adsorption isotherms (77 K, Micromeritics ASAP 2010) following Dubinin's theory for the volume filling of micropores [20]. Dubinin-Radushkevich equation led to the volume $W_{o}$ of the micropores, their average width $L_{o}$ and the surface area of their walls, $S_{\mathrm{mi}}$. Moreover, the comparison of the isotherm on the given sample with the adsorption data for a non-porous reference carbon black Vulcan-3G, provided information on the total pore volume and the external (non microporous) area $S_{e}$ of the carbon $[20,21]$ (Table 1).

Beside vapour adsorption, immersion calorimetry was also used as a complementary tool for the characterization of the samples (Table 2). This technique, related to Dubinin's theory, is described in detail elsewhere [20]. The enthalpies of immersion into benzene, $\Delta_{\mathrm{i}} \mathrm{H}\left(\mathrm{C}_{6} \mathrm{H}_{6}\right)$, and into carbon tetrachloride, $\Delta_{\mathrm{i}} \mathrm{H}\left(\mathrm{CCl}_{4}\right)$, 
determined for most samples, provide information on the accessibility of the porous system to the various electrolytes. $\mathrm{CCl}_{4}$ has a size $(0.63-0.65 \mathrm{~nm})$ similar to that of the $\left(\mathrm{C}_{2} \mathrm{H}_{5}\right)_{4} \mathrm{~N}^{+}$ion $(0.68 \mathrm{~nm}[22,23])$. Moreover, $\Delta_{\mathrm{i}} \mathrm{H}\left(\mathrm{CCl}_{4}\right)$ is also related to the gravimetric capacitance in the $\left(\mathrm{C}_{2} \mathrm{H}_{5}\right)_{4} \mathrm{NBF}_{4}$ /acetonitrile electrolyte [9].

The chemical characteristics of resin derived-carbons are determined by the chemical composition of the resin precursors, the nature of the activation process and any post treatment [24]. The present carbons are high purity with a relatively low level of surface functionalities. The values of the enthalpy of immersion into water, $\Delta_{\mathrm{i}} \mathrm{H}\left(\mathrm{H}_{2} \mathrm{O}\right)$, reported in Table 2 reflect quantitatively the presence of oxygen-containing surface complexes [21], part of which are responsible for pseudo-capacitance effects $[4,6,8]$. In the case of samples M6 and M10 further oxygen was introduced by treating the carbon dioxide activated carbonised resin with air at $300^{\circ} \mathrm{C}$ for 12 hours. This leads to higher enthalpies of immersion into water (Table 2).

\subsection{Electrochemical measurements}

The properties for charge storage were tested in two-electrode cells by galvanostatic charge-discharge voltage cycles (potentiostat-galvanostat Autolab-Ecochimie PGSTAT 30) at current densities of 50 and $6000 \mathrm{~mA} \mathrm{~g}^{-1}$ from 0 to $0.8 \mathrm{~V}$ in $2 \mathrm{M} \mathrm{H}_{2} \mathrm{SO}_{4}$ aqueous electrolyte and from 0 to $2 \mathrm{~V}$ in $1 \mathrm{M}\left(\mathrm{C}_{2} \mathrm{H}_{5}\right)_{4} \mathrm{NBF}_{4}$ in acetonitrile (Table 3 ). (The current density of $6000 \mathrm{~mA} \mathrm{~g}^{-1}$ corresponds approximately to $70 \mathrm{~mA} \mathrm{~cm}{ }^{-2}$ and $\mathrm{C}_{50}$ is close to the limiting capacitance $\mathrm{C}_{0}$ at $1 \mathrm{~mA} \mathrm{~cm}-2$ used elsewhere $[6,9]$. The electrodes consist of carbon pellets (8-9 $\mathrm{mg}$ in weight, $8 \mathrm{~mm}$ in diameter) obtained by pressing a mixture of carbon (75 wt\%), polyvinylidene fluoride (20 wt\%) binder and carbon black (Super P, 5 wt\%).

All capacitance values refer to the capacitance and mass of carbon in a single electrode. They were obtained by using the expression $\mathrm{C}_{\text {electrode }}\left(\mathrm{Fg}^{-1}\right)=4 \mathrm{C}_{\text {cell }}$. Although the effect of the cations and anions is mixed in the overall capacitance of the cell, the electrode with the lower capacitance dominates the cell performance. 
This is especially important in the case of the aprotic electrolyte with bulky cation.

\section{Results and Discussion}

\subsection{Specific surface capacitances}

A careful selection of the carbon precursor and the activation conditions led to high specific surface areas and to different pore size distributions in both the micropore and the mesopore ranges (Table 1). The micropore volumes, $W_{0}$, and the corresponding surface areas, $S_{\mathrm{mi}}$, are obtained from the analysis of the nitrogen adsorption isotherm at $77 \mathrm{~K}$ by applying Dubinin's theory, as described in detail elsewhere [20]. On the other hand, the technique based on the comparison of the adsorption isotherm with a reference isotherm $[20,21]$ leads to the total surface area $S_{\text {comp }}$, the external (non-microporous) surface area $S_{e}$ and the total pore volume $V_{\text {tot. }}$ The latter is the sum of the microporous and mesoporous volumes $W_{0}+V_{\text {meso. }}$. As seen in Table 1 , there is a good agreement between $S_{\text {total }}$ and $S_{\text {comp }}$, whereas $S_{B E T}$ diverges from these values outside the range of micropore widths $L_{\circ} 0.8-1.1 \mathrm{~nm}$. This feature has been discussed elsewhere $[6,20,21]$. Surface related quantities were calculated by using $S_{a v}=\left(S_{c o m p}+S_{\text {total }}\right) / 2$. It also appears that the enthalpies of immersion $\Delta_{\mathrm{i}} \mathrm{H}\left(\mathrm{C}_{6} \mathrm{H}_{6}\right)$ calculated from the parameters of Dubinin's equation are in good agreement with the experimental values given in Table 2, which may be regarded as a test for self-consistency between the different techniques.

The average micropore sizes are calculated from the characteristic energy $E_{o}$ of the nitrogen isotherm [20] and the mesopore size distributions (diameters $D_{K J S}$ ) are obtained by applying the Kruk-Jaroniec-Sayari (KJS) method to the adsorption isotherm branch [25]. Typical examples of mesoporosities are shown in Fig. 1.

The carbons, which are all microporous, have been divided into four different series (I-IV) on the basis of the porosity above $2 \mathrm{~nm}$, the upper limit of microporosity.

Series I (carbons M1 to M5) has practically no mesoporosity and $S_{e}$ does not exceed 
10 to $15 \mathrm{~m}^{2} \mathrm{~g}^{-1}$. Therefore, these carbons may be regarded as exclusively microporous with $L_{o}$ between 0.66 and $1.25 \mathrm{~nm}$. Series II contains sample M6, which displays the only bimodal mesoporosity observed in this study. Series III (M7 to M10) is characterized by relatively narrow mesoporosities with maxima between 24.4 and $31.5 \mathrm{~nm}$. Finally, series IV (M11, M12) corresponds to carbons with a broad porosity above $10 \mathrm{~nm}$. The surface areas $\mathrm{S}_{\mathrm{e}}$ associated with the carbons of series IIIV are in the range of 81 to $299 \mathrm{~m}^{2} \mathrm{~g}^{-1}$.

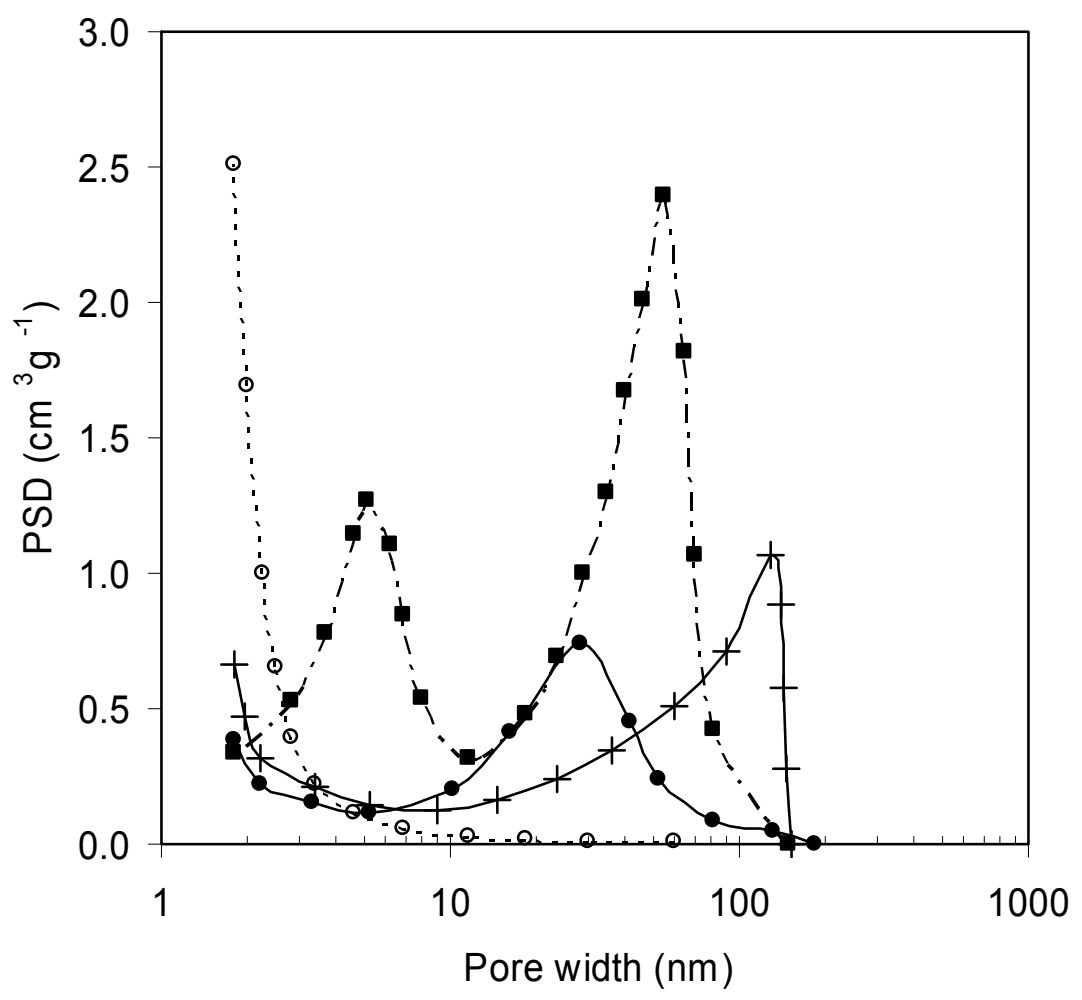

Figure 1. Mesopore size distributions obtained by applying the Kruk-Jaroniec-Sayari (KJS) method to MAST-carbons M5 (०), M6 (•), M8 (•), M12 (+).

The classification allows interesting comparisons between pairs of carbons of series I and series II-IV with similar micropore sizes, but higher porosities for the latter. For example, $\mathrm{M} 1$ and $\mathrm{M} 11$ have average micropore widths $\mathrm{L}_{\circ}$ around $0.7 \mathrm{~nm}$, but widely different surface areas $S_{e}$ (respectively 10 and $81 \mathrm{~m}^{2} \mathrm{~g}^{-1}$ ) due to the macroporosity of M11. The same is true for the pairs [M2+M8], [M4+M12] and the group $[M 5+M 9 / M 10]$. It follows that the present MAST-carbons, derived from the 
same precursor, provide a suitable basis for the study of the effect of pore size distributions on the electrochemical behaviour of carbons in supercapacitors.

As shown in Table 3, the specific double layer capacitance relative to the carbon mass in a single electrode at low current density $\left(50 \mathrm{~mA} \mathrm{~g}^{-1}\right), \mathrm{C}_{50}$, ranges from 119 to $199 \mathrm{~F} \mathrm{~g}^{-1}$ in aqueous $\mathrm{H}_{2} \mathrm{SO}_{4}$, in good agreement with data reported in the literature for typical activated carbons [2, 4, 6, 7, 9]. This leads to the corresponding specific capacitances $C_{50} / S_{a v}$ given in Table 3. They vary between 0.111 and $0.163 \mathrm{~F} \mathrm{~m}^{-2}$, which reflects the contribution of pseudo-capacitance effects. This is confirmed by its correlation with the specific enthalpy of immersion into water, $h_{i}\left(H_{2} O\right)=\Delta_{i} H\left(H_{2} O\right) / S_{a v}$ (Table 2). The latter varies between -0.020 and $-0.075 \mathrm{~J} \mathrm{~m}^{-2}$, where the lower bound corresponds practically to the wetting of a carbon without surface oxygen [21]. This means that in the case of the acidic electrolyte the minimum surface capacitance of the present carbons is around $0.111 \mathrm{~F} \mathrm{~m}^{-2}$. It increases with the amount of the oxygen-containing surface complexes leading to the evolution of $\mathrm{CO}$ in TPD (thermally programmed desorption) [6].

As shown in Fig. 2, the gravimetric capacitances of the MAST carbons $\mathrm{C}_{50}$ (acidic) and the enthalpies of immersion into benzene and water follow the correlation suggested earlier [9] for more than 80 different activated carbons, namely

$$
\mathrm{C}_{\mathrm{o}}(\text { acidic })\left[\mathrm{F} \mathrm{g}^{-1}\right]=-(0.56 \pm 0.02) \Delta_{\mathrm{i}} \mathrm{H}\left(\mathrm{C}_{6} \mathrm{H}_{6}\right)-(0.047 \pm 0.056) \Delta_{\mathrm{i}} \mathrm{H}\left(\mathrm{H}_{2} \mathrm{O}\right)
$$

$\mathrm{C}_{50}$ being close to $\mathrm{C}_{0}$ determined at $1 \mathrm{~mA} \mathrm{~cm}{ }^{-2}$, this observation confirms the general pattern. 


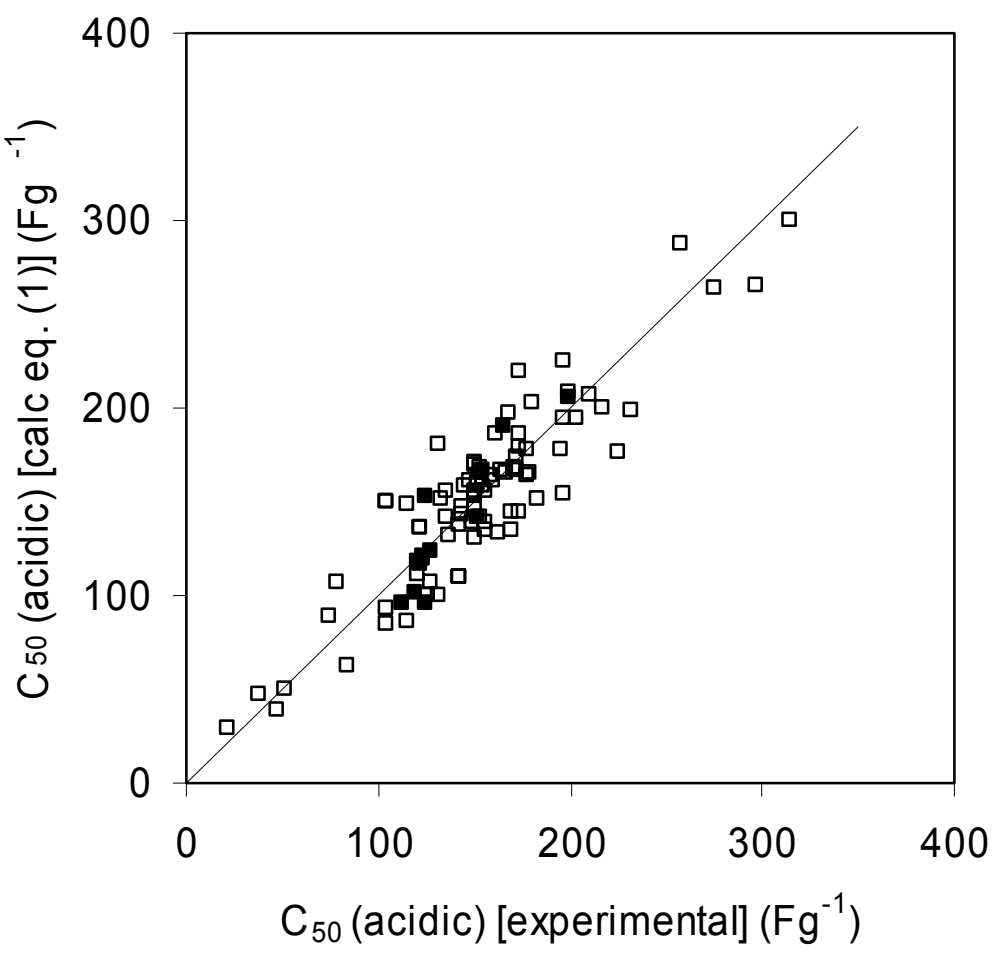

Figure 2. Calculated and experimental gravimetric capacitances $C_{50}$ (acidic) using Eqn (1). Earlier study (口) [9] and MAST-carbons (ロ)

In the case of the aprotic electrolyte $\left(\mathrm{C}_{2} \mathrm{H}_{5}\right)_{4} \mathrm{NBF}_{4} /$ acetonitrile, the situation is different, due to the fact that at low current densities $\mathrm{C}$ (aprotic) is practically independent of the oxygen-containing surface complexes (At higher densities, they may act as obstacles and reduce ionic mobility, which leads to a decrease in C) [9]. On the other hand, in the case of carbons with a substantial porosity below $0.7 \mathrm{~nm}$ or presenting 'gate' effects at the entrance of wider pores, the accessibility of the aprotic $\left(\mathrm{C}_{2} \mathrm{H}_{5}\right)_{4} \mathrm{~N}^{+}$cation is reduced with respect to the acidic cation [9]. It follows that the available surface area is smaller than determined with the help of small probes such as $\mathrm{N}_{2}$ or $\mathrm{C}_{6} \mathrm{H}_{6}$. This means that the specific capacitance $\mathrm{C}_{50}$ (aprotic)/S $\mathrm{S}_{\mathrm{av}}$ is too low. Theoretically, in the case of equal accessibility to $\mathrm{CCl}_{4}$ and $\mathrm{C}_{6} \mathrm{H}_{6}$, the ratio $\Delta_{\mathrm{i}} \mathrm{H}\left(\mathrm{CCl}_{4}\right) /$ $\Delta_{\mathrm{i}} \mathrm{H}\left(\mathrm{C}_{6} \mathrm{H}_{6}\right)=0.96$. In view of the similar sizes of $\mathrm{CCl}_{4}$ and $\left(\mathrm{C}_{2} \mathrm{H}_{5}\right)_{4} \mathrm{~N}^{+}$, this ratio is an indicator for the accessibility of the microporous structure to the ion. For example, the value of 0.45 found for sample M1 confirms that the capacitance of $0.033 \mathrm{~F} \mathrm{~m}^{-2}$ is not 
realistic, but due to a reduced accessibility. The true value for the present carbons is probably close to $0.09-010 \mathrm{~F} \mathrm{~m}^{-2}$, in agreement with typical porous carbons [9] which have not been subjected to specific chemical or thermal treatments following their preparation. This regular behaviour is also confirmed by the good correlation between $\mathrm{C}_{50}$ (aprotic) and $\Delta_{\mathrm{i}} \mathrm{H}\left(\mathrm{CCl}_{4}\right)$ for most of the samples. As suggested by the data of Table 2, their average ratio $\left(0.66 \pm 0.09 \mathrm{~F} \mathrm{~J}^{-1}\right)$ is close to the average value of $0.63 \mathrm{~F} \mathrm{~J}^{-1}$ reported for 31 untreated carbons with pore sizes $L_{\circ}$ between 0.5 and 10 $\mathrm{nm}[9]$.

The present study confirms the detrimental effect of mesopores on the specific capacitance related to the electrode volume [26]. For our carbons, $\mathrm{C}_{50}$ (acidic) $/ \mathrm{V}_{\text {electrode }}$ is approximately $60 \mathrm{~F} \mathrm{~cm}^{-3}$ for series I (only micropores) and only 43-47 $\mathrm{F} \mathrm{cm}^{-3}$ for series III (micropores + mesopores). In the case of the aprotic medium, the ratio $\mathrm{C}_{50}$ (aprotic)/ $\mathrm{V}_{\text {electrode }}$ drops to 46 and $26 \mathrm{~F} \mathrm{~cm}^{-3}$ for series I and III, respectively. From a technological point of view, this decrease is important since it does not contribute to the development of small supercapacitors.

\subsection{Contribution of the pores above $2 \mathrm{~nm}$ to the performance of supercapacitors}

The present series of carbons also allows an assessment of the role of pores wider than $2 \mathrm{~nm}$ in the performances of supercapacitors. It is assumed that pores larger than $2 \mathrm{~nm}$ significantly enhance the capacitor performance by providing wider transport paths for ions diffusion into smaller pores [2, 11-16]. However, this view can be challenged by the following analysis based on the comparison of series I and II-IV (Table 1), where similar micropore systems can be found with and without a wider porosity, all samples being derived from the same precursor.

First of all, it confirms that the approach based on different contributions from micropores and mesopores to the overall capacitance $[8,13]$ is too limited $[26,27]$. The contribution of the wider pores to the gravimetric capacitance appears to be 
small, as it results from their surface area and not from the volume. It has been already shown that the specific capacitance in mesoporous carbons is the same as in microporous carbons $[6,21,28]$. The contribution is therefore equal to $S_{e}$ multiplied by the specific capacitance of the given carbon or simply to $\mathrm{C}_{50}\left(\mathrm{~S}_{\mathrm{e}} / \mathrm{S}_{\mathrm{av}}\right)$. On the other hand, a possible contribution of mesopores to the dynamic performances should be revealed by the comparison of the decrease in $\mathrm{C}$ with the current density under standard conditions, for example the ratio $C_{6000} / C_{50}$. Figures 3 and 4 compare these relative capacitances for the twelve carbons in the $\mathrm{H}_{2} \mathrm{SO}_{4}$ and $\left(\mathrm{C}_{2} \mathrm{H}_{5}\right)_{4} \mathrm{NBF}_{4}$ /acetonitrile electrolytes, both as functions of $\mathrm{L}_{\mathrm{o}}$.

Fig. 3 shows that $\mathrm{C}_{6000} / \mathrm{C}_{50}$ is practically independent of the average micropore width between 0.6 and $1.2 \mathrm{~nm}$. No systematic increase is observed within pairs/groups of carbons with similar micropore systems with and without larger pores namely $(M 1+M 11),(M 2+M 8),(M 4+M 12)$ and $(M 5+M 9 / M 10)$. The small increase observed for some cases would not justify the claim of an improvement due to the wider pores in the same type of carbon. This probably reflects the total accessibility of the micropore systems to the relatively small ions of the aqueous electrolyte. 


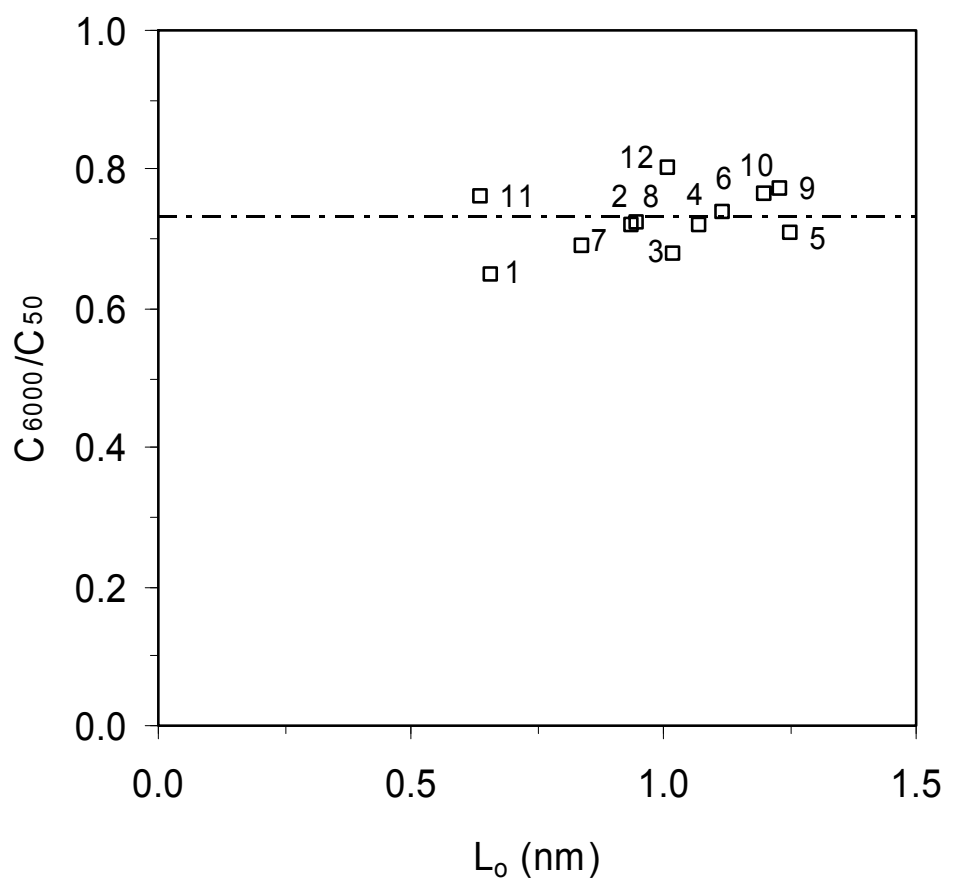

Figure 3. Evolution of normalised specific capacitance $\left(\mathrm{C}_{6000} / \mathrm{C}_{50}\right)$ in $2 \mathrm{M} \mathrm{H}_{2} \mathrm{SO}_{4}$ with the average micropore width for MAST-carbons

In the case of the aprotic electrolyte, the increase of $\mathrm{C}_{6000} / \mathrm{C}_{50}$ (Fig. 4) clearly reflects the ratio of the dimension of the larger $\left(\mathrm{C}_{2} \mathrm{H}_{5}\right)_{4} \mathrm{~N}^{+}$ion $(0.68 \mathrm{~nm})$ and the average micropore width $L_{o}(0.6$ to $1.2 \mathrm{~nm})$. Acetonitrile being smaller than the $\left(\mathrm{C}_{2} \mathrm{H}_{5}\right)_{4} \mathrm{~N}^{+}$ cation, it fills all pores (like $\mathrm{C}_{6} \mathrm{H}_{6}$ or $\mathrm{CH}_{2} \mathrm{Cl}_{2}$ ) and at least a planar solvatation is likely in slit-shaped micropores of 0.65 to $0.70 \mathrm{~nm}[29,30]$. 


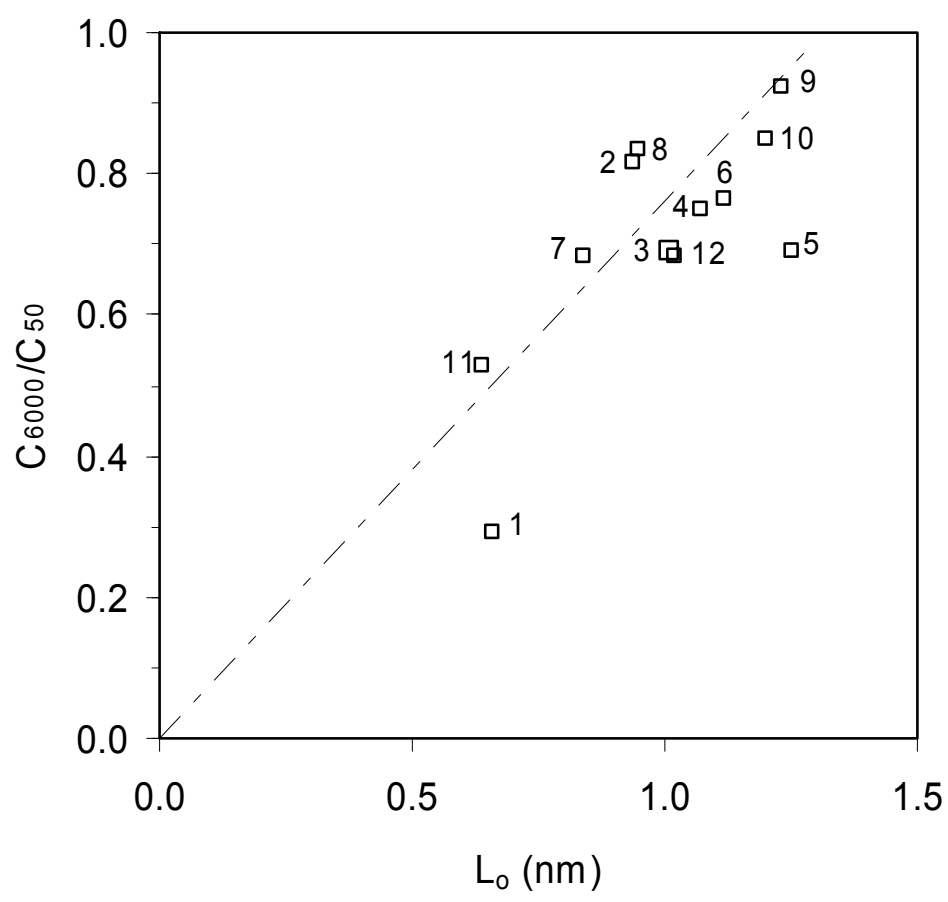

Figure 4. Evolution of normalised specific capacitance $\left(\mathrm{C}_{6000} / \mathrm{C}_{50}\right)$ in $1 \mathrm{M}$ $\left(\mathrm{C}_{2} \mathrm{H}_{5}\right)_{4} \mathrm{NBF}_{4} /$ acetonitrile with the average micropore width for MAST-carbons.

The profile displayed here indicates that the diffusion of aprotic cations is strongly hindered by the smaller micropores. The mobility is dictated by the largest ion, here the $\left(\mathrm{C}_{2} \mathrm{H}_{5}\right)_{4} \mathrm{~N}^{+}$cation, with a size close to that of $\mathrm{CCl}_{4}$.

An average width around $1.2 \mathrm{~nm}$ appears to optimize the rate capability of carbons at high current density and it is important to point out that it is similar to that observed for essentially mesoporous carbons [28]. This experimental observation contrasts with the optimum size of 0.7 to $0.8 \mathrm{~nm}$ reported for carbide-derived carbons [22]. The difference may reflect both the precursor materials and the carbonization treatment.

On the other hand, it appears that for the same pairs of carbons, the difference is still small, with the exceptions of M1 and M11. This could be explained by the reduction in the micropore lengths rather than their width during the formation of the wider pores. However, in view of the similarities between $L_{o}$ (around $0.7 \mathrm{~nm}$ ) and the size of the ion $(0.68 \mathrm{~nm}), \mathrm{M} 1$ and M11 are exceptions anyway and it would appear 
that for carbons with wider micropores the contribution of the mesopores to the ionic mobility is smaller than assumed.

Further evidence is provided by the fact that the enhancement of the power capability suggested for microporous carbons with a significant mesoporosity, is not confirmed by the Ragone-type plots (Fig. 5). The comparison of the pairs [M2+M8] and [M5+M10], groups of carbons with a micropore size around $0.95 \mathrm{~nm}$ and 1.23 $\mathrm{nm}$, respectively, confirms similar performance within materials with and without mesoporosity fraction.

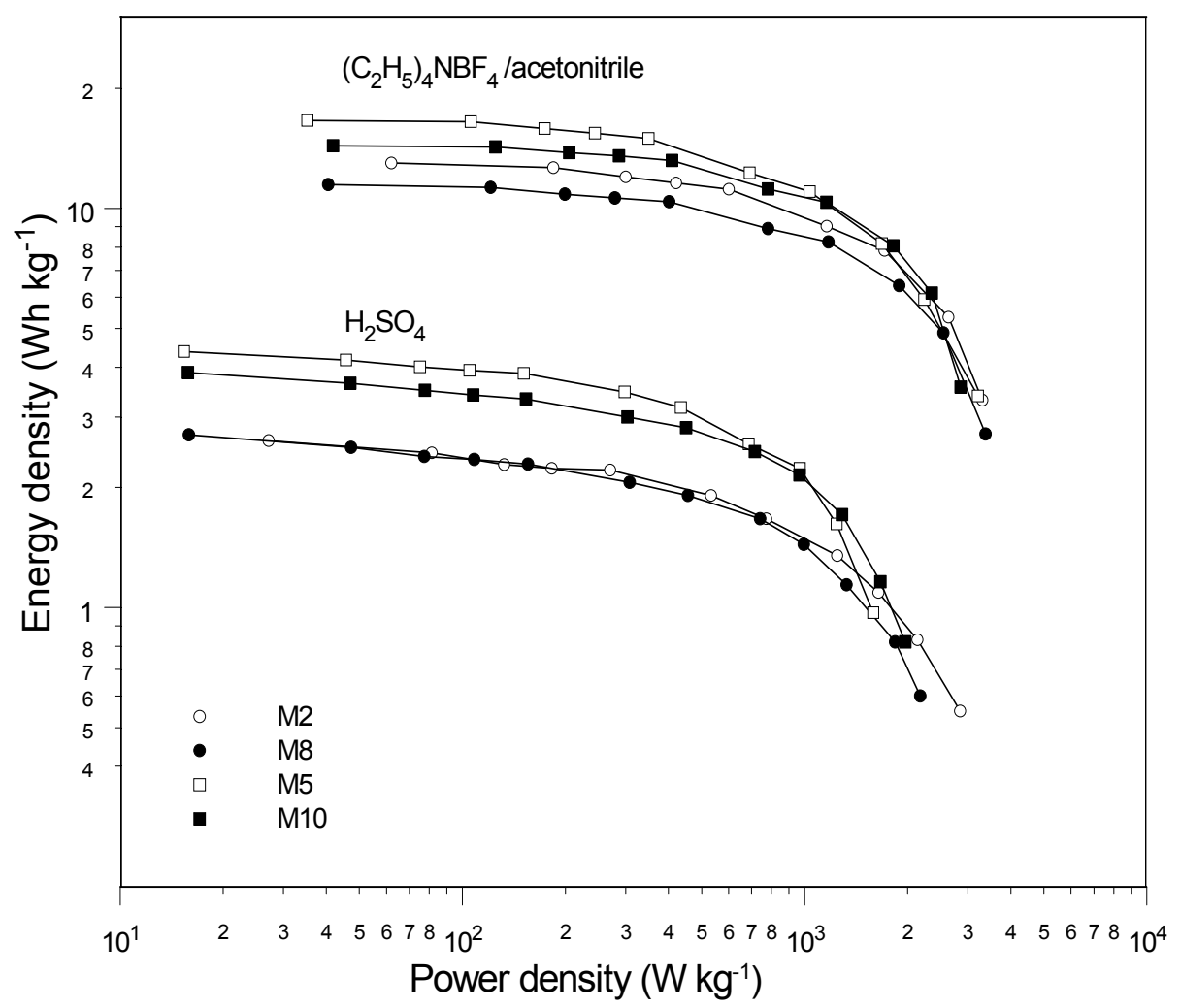

Figure 5. Power density vs. Energy density for carbons with a micropore size around $0.95 \mathrm{~nm}(\mathrm{M} 2+\mathrm{M} 8)$ and $1.24 \mathrm{~nm}$ (M5+M10) and different mesoporosity fraction.

\section{Conclusions}

The present study shows that the electrochemical properties of MAST-based carbons fit well into the general pattern established earlier, for both the acidic and the aprotic electrolytes. It also confirms the similar accessibility in pores wider than $0.8 \mathrm{~nm}$, provided that no 'gate' effects are present. Moreover, the comparison of carbons 
obtained from the same precursor, with and without a significant mesoporosity, suggests that the latter does not contribute significantly to the enhancement of capacitor performance.

The good rate capability of the microporous carbons may be due to a reduction in the micropore length.

\section{References}

1. Miller JR, Burke AF. Electrochemical capacitors: Challenges and Opportunities for Real World Applications. Electrochem Soc Interface 2008; 17(1): 53-7.

2. Pandolfo AG, Hollenkamp AF. Carbon properties and their role in supercapacitors. J Power Sources 2006; 157(1): 11-27.

3. Kodama M, Yamashita J, Soneda Y, Hatori H, Nishimura S, Kamegawa K. Structural characterization and electric double layer capacitance of template carbons. Mat Sci Eng B 2004; 108(1-2): 156-61.

4. Bleda-Martínez MJ, Maciá-Agulló JA, Lozano-Castelló D, Morallón, CazorlaAmorós D, Linares-Solano A. Role of surface chemistry on electric double layer capacitance of carbon materials. Carbon 2005; 43(13): 2677-84.

5. Frackowiak E, Lota G, Machnikowski J, Vix-Guterl C, Béguin F. Optimisation of supercapacitors using carbons with controlled nanotexture and nitrogen content. Electrochim Acta 2006; 51(11): 2209-14.

6. Centeno TA, Stoeckli F. The role of textural characteristics and oxygencontaining surface groups in the supercapacitor performances of activated carbons. Electrochim Acta 2006; 52(2): 560-6.

7. Raymundo-Piñero E, Kierzek K, Machnikowski J, Béguin F. Relationship between the nanoporous texture of activated carbons and their capacitance properties in different electrolytes. Carbon 2006; 44(12): 2498-507.

8. Shi H. Activated carbons and double layer capacitance. Electrochim Acta 1996; 41(10): 1633-9.

9. Centeno TA, Fernandez JA, Stoeckli F. Correlation between heats of immersion and limiting capacitances in porous carbons. Carbon 2008 ; 46(7) : 1025-30.

10. Largeot C, Portet C, Chmiola J, Taberna PL, Gogotsi Y, Simon P. Relation between the ion size and pore size for an electric double-layer capacitor. J Am 
Chem Soc 2008; $130: 2730-1$.

11. Fuertes AB, Picó F, Rojo JM. Influence of pore structure on electric doublelayer capacitance of template mesoporous carbons. J Power Sources 2004; 133(2): 329-36.

12. Liu HY, Wang KP, Teng H. A simplified preparation of mesoporous carbon and the examination of the carbon accessibility for electric double layer formation. Carbon 2005 ; 43(3) 559-66.

13. Gryglewicz G, Machnikowski J, Lorenc-Grabowska E, Lota G, Frackowiak E. Effect of pore size distribution of coal-based activated carbons on double layer capacitance. Electrochim Acta 2005; 50(5):1197-206.

14. Hsieh CT, Lin YT. Synthesis of mesoporous carbon composite and its electric double-layer formation behaviour. Micropor Mesopor Mater 2006; 93(1-3):2329.

15. Zhang L, Liu H, Wang M, Chen L. Structure and electrochemical properties of resorcinol-formaldehyde polymer-based carbon for electric double-layer capacitors. Carbon 2007; 45(7): 1439-45.

16. Xia K, Gao Q, Jiang J, Hu J. Hierarchical porous carbons with controlled micropores and mesopores for supercapacitor electrode materials. Carbon $2008 ; 46(13)$ : 1718-26.

17. Tennison SR. Phenolic-resin-derived activated carbons. Appl Catal A Gen 1998; 173(2) 289-311.

18. Gun'ko VM, Kozynchenko OP, Turov AA, Tennison SR, Zarko VI, Nychiporuk YM et al. Structural and adsorption studies of activated carbons derived from porous phenolic resins. Colloids Surface A 2008; 317(1-3): 377-87.

19. Tennison SR, Kozynchenko O, Strelko V, Blackburn AJ. Porous carbons. US Patent 2008032092, 2008

20. Stoeckli F. In: Patrick J, editor. Porosity in carbons-characterization and applications. London: Arnold; 1995. p. 67-97.

21. Centeno TA, Stoeckli F. In: Gupta V, editor. Recent Advances in Supercapacitors. Kerala: Transworld Research Network; 2006, p. 57-77.

22. Chmiola J, Yushin G, Gogotsi Y, Portet C, Simon P, Taberna PL. Anomalous increase in carbon capacitance at pore sizes less than 1 nanometer. Science 2006; 313: 1760-3.

23. Morita M, Watanabe S, Ishikawa M, Tamai $H$, Yasuda $H$. Utilization of activated carbon fiber with mesopore structure for electric double layer capacitors. Electrochemistry 2001; 69(6): 462-6. 
24. Pigamo A, Besson M, Blanc B, Gallezot P, Blackburn AJ, Kozynchenko O et al. Effect of oxygen functional groups on synthetic carbons on liquid phase oxidation of cyclohexanone. Carbon 2002; 40(8): 1267-78.

25. Kruk M, Jaroniec M, Sayari A. Application of large pore MCM-41 molecular sieves to improve pore size analysis using nitrogen adsorption measurements. Langmuir 1997; 13 (23) 6267-73.

26. Chmiola J, Yushin G, Dash R, Gogotsi Y. Effect of pore size and surface area of carbide derived carbons on specific capacitance. J Power Sources 2006; 158(1): 765-72.

27. Jänes $A$, Kurig $H$, Lust $E$. Characterisation of activated nanoporous carbon for supercapacitor electrode materials. Carbon 2007; 45(6): 1226-33.

28. Fernández JA, Morishita $T$, Toyoda $M$, Inagaki $M$, Stoeckli $F$, Centeno TA. Performance of mesoporous carbons derived from poly(vinyl alcohol) in electrochemical capacitors. J Power Sources 2008; 175(1): 675-9.

29. Huang J, Sumpter BG, Meunier V. Theoretical model for nanoporous carbon supercapacitors. Angew Chem Int Ed 2008; 47: 520-4.

30. Chmiola J, Largeot C, Taberna, PL, Simon P, Gogotsi Y. Desolvation of ions in subnanometer pores and its effect on capacitance and double-layer theory. Angew Chem Int Ed 2008; 47: 3392-5 
Table 1.Main textural characteristics of the phenolic resin-derived activated carbons

\begin{tabular}{|c|c|c|c|c|c|c|c|c|c|c|c|c|}
\hline Series & Carbon & $\begin{array}{c}V_{\text {total }} \\
\left(\mathrm{cm}^{3} \mathrm{~g}^{-1}\right)\end{array}$ & $\begin{array}{c}W_{\circ} \\
\left(\mathrm{cm}^{3} \mathrm{~g}^{-1}\right)\end{array}$ & $\begin{array}{c}\mathrm{E}_{\mathrm{o}} \\
\left.(\mathrm{kJ} \mathrm{mol})^{-1}\right)\end{array}$ & $\begin{array}{c}\mathrm{L}_{\mathrm{o}} \\
(\mathrm{nm})\end{array}$ & $\begin{array}{l}D_{\mathrm{KJS}} \\
(\mathrm{nm})\end{array}$ & $\begin{array}{c}\mathrm{S}_{\mathrm{BET}} \\
\left(\mathrm{m}^{2} \mathrm{~g}^{-1}\right)\end{array}$ & $\begin{array}{l}\mathrm{S}_{\text {comp }} \\
\left(\mathrm{m}^{2} \mathrm{~g}^{-1}\right)\end{array}$ & $\begin{array}{c}\mathrm{S}_{\mathrm{mi}} \\
\left(\mathrm{m}^{2} \mathrm{~g}^{-1}\right)\end{array}$ & $\begin{array}{c}\mathrm{S}_{\mathrm{e}} \\
\left(\mathrm{m}^{2} \mathrm{~g}^{-1}\right)\end{array}$ & $\begin{array}{c}S_{\text {total }}=S_{m i}+S_{e} \\
\left(m^{2} g^{-1}\right)\end{array}$ & $\begin{array}{c}S_{a v}=\left(S_{\text {comp }}+S_{\text {total }}\right) / 2 \\
\left(\mathrm{~m}^{2} \mathrm{~g}^{-1}\right)\end{array}$ \\
\hline \multirow{5}{*}{1} & M1 & 0.35 & 0.33 & 27.7 & 0.66 & - & 710 & 875 & 1000 & 10 & 1010 & 943 \\
\hline & M2 & 0.55 & 0.51 & 22.9 & 0.94 & - & 1105 & 1047 & 1085 & 11 & 1096 & 1072 \\
\hline & M3 & 0.60 & 0.54 & 22.0 & 1.02 & - & 1200 & 1046 & 1059 & 8 & 1067 & 1057 \\
\hline & M4 & 0.58 & 0.50 & 21.5 & 1.07 & - & 1190 & 1061 & 935 & 13 & 948 & 1005 \\
\hline & M5 & 0.85 & 0.71 & 20.1 & 1.25 & - & 1773 & 1256 & 1136 & 6 & 1142 & 1199 \\
\hline II & M6 & 1.50 & 0.36 & 21.0 & 1.12 & $5.2-54.0$ & 909 & 947 & 643 & 269 & 912 & 930 \\
\hline \multirow{4}{*}{ III } & M7 & 0.55 & 0.29 & 24.2 & 0.84 & 24.4 & 648 & 880 & 690 & 187 & 877 & 879 \\
\hline & M8 & 0.71 & 0.45 & 22.8 & 0.95 & 26.5 & 961 & 967 & 947 & 140 & 1087 & 1027 \\
\hline & M9 & 0.85 & 0.64 & 20.2 & 1.23 & 29.7 & 1472 & 1079 & 1041 & 116 & 1157 & 1118 \\
\hline & M10 & 1.36 & 0.63 & 20.4 & 1.20 & 31.5 & 1488 & 1288 & 1050 & 299 & 1349 & 1319 \\
\hline \multirow{2}{*}{ IV } & M11 & 0.27 & 0.25 & 26.5 & 0.71 & $\begin{array}{c}\text { Broad PSD } \\
>10\end{array}$ & 550 & 794 & 704 & 81 & 785 & 790 \\
\hline & M12 & 0.59 & 0.51 & 22.1 & 1.01 & $\begin{array}{c}\text { Broad PSD } \\
\quad>10\end{array}$ & 1140 & 1140 & 1010 & 110 & 1120 & 1130 \\
\hline
\end{tabular}


Table 2. Enthalpies of immersion of the phenolic resin-based activated carbons

\begin{tabular}{|c|c|c|c|c|c|c|c|}
\hline Series & Carbon & $\begin{array}{c}-\Delta_{\mathrm{i}} \mathrm{H}\left(\mathrm{C}_{6} \mathrm{H}_{6}\right) \\
\left(\mathrm{J} \mathrm{g}^{-1}\right)\end{array}$ & $\begin{array}{c}-\Delta_{\mathrm{i}} \mathrm{H}\left(\mathrm{CCl}_{4}\right) \\
\left(\mathrm{J} \mathrm{g}^{-1}\right)\end{array}$ & $\Delta_{\mathrm{i}} \mathrm{H}\left(\mathrm{CCl}_{4}\right) / \Delta_{\mathrm{i}} \mathrm{H}\left(\mathrm{C}_{6} \mathrm{H}_{6}\right)$ & $\begin{array}{c}-\Delta_{\mathrm{i}} \mathrm{H}\left(\mathrm{H}_{2} \mathrm{O}\right) \\
\left(\mathrm{J} \mathrm{g}^{-1}\right)\end{array}$ & $\begin{array}{l}-\mathrm{h}_{\mathrm{i}}\left(\mathrm{H}_{2} \mathrm{O}\right) \\
\left(\mathrm{J} \mathrm{m}^{-2}\right)\end{array}$ & $\begin{array}{c}\mathrm{C}_{50}(\text { aprotic }) / \Delta_{\mathrm{i}} \mathrm{H}\left(\mathrm{CCl}_{4}\right) \\
\left(\mathrm{F} \mathrm{J}^{-1}\right)\end{array}$ \\
\hline \multirow{5}{*}{ I } & M1 & 125.9 & 56.2 & 0.45 & 22.3 & 0.024 & 0.55 \\
\hline & M2 & 151.7 & 166.7 & 1.10 & 21.9 & 0.020 & 0.58 \\
\hline & M3 & 190.5 & 167.1 & 0.86 & 47.6 & 0.075 & 0.57 \\
\hline & M4 & 152.4 & 91.0 & 0.58 & 27.8 & 0.028 & 0.83 \\
\hline & M5 & 209.9 & 196.3 & 0.94 & 59.7 & 0.050 & 0.63 \\
\hline II & M6 & 118.5 & 101.9 & 0.86 & 70.1 & 0.075 & 0.75 \\
\hline \multirow{2}{*}{ III } & M8 & 133.3 & 124.4 & 0.93 & 38.5 & 0.037 & 0.68 \\
\hline & M10 & 197.8 & 175.6 & 0.89 & 85.2 & 0.065 & 0.64 \\
\hline IV & M12 & 191.6 & 146.8 & 0.77 & 31.7 & 0.028 & 0.71 \\
\hline
\end{tabular}


Table 3. Electrochemical properties of the phenolic resin-based activated carbons

\begin{tabular}{|c|c|c|c|c|c|}
\hline & \multirow[t]{2}{*}{ Carbon } & \multicolumn{2}{|c|}{$\begin{array}{c}\mathrm{C}_{50} \\
\mathrm{H}_{2} \mathrm{SO}_{1}\end{array}$} & \multicolumn{2}{|c|}{$\begin{array}{c}\mathrm{C}_{50} \\
{\left[\left(\mathrm{C}_{2} \mathrm{H}_{5}\right)_{4} \mathrm{NBF}_{4} / \text { acetonitrile }\right]}\end{array}$} \\
\hline & & $\left(\mathrm{F} \mathrm{g}^{-1}\right)$ & $\left(\mathrm{F} \mathrm{m}^{-2}\right)$ & $\left(\mathrm{F} \mathrm{g}^{-1}\right)$ & $\left(\mathrm{F} \mathrm{m}^{-2}\right)$ \\
\hline \multirow{5}{*}{1} & M1 & 119 & 0.126 & 31 & 0.033 \\
\hline & M2 & 121 & 0.113 & 97 & 0.090 \\
\hline & M3 & 155 & 0.147 & 95 & 0.090 \\
\hline & M4 & 128 & 0.127 & 76 & 0.076 \\
\hline & M5 & 166 & 0.138 & 124 & 0.103 \\
\hline II & M6 & 152 & 0.163 & 76 & 0.082 \\
\hline \multirow{4}{*}{ III } & M7 & 112 & 0.127 & 47 & 0.053 \\
\hline & M8 & 124 & 0.121 & 85 & 0.083 \\
\hline & M9 & 159 & 0.142 & 105 & 0.094 \\
\hline & M10 & 199 & 0.151 & 113 & 0.086 \\
\hline \multirow{2}{*}{ IV } & M11 & 125 & 0.158 & 19 & 0.024 \\
\hline & M12 & 125 & 0.111 & 105 & 0.093 \\
\hline
\end{tabular}

